\title{
Effect of Adiponectin Hormone on Serum Lipoproteins Levels in Female Rats
}

\author{
H, A. A. Al-Baka`a \\ Coll. of Vet. Med.1/Univ. of Kufa \\ hussein.abdlridha@uo.kufa.edu.iq
}

\begin{abstract}
:
This investigation aimed to study effect of adiponectin hormone on serum lipoproteins levels in female rats. For this purpose, thirteen female rats were divided into treated and control groups. Each animal in treated group received a daily intraperitoneal 25microgram does of adiponectin dissolved in $0.2 \mathrm{ml}$ normal saline for fifteen respective days. In the same time each animal in control group received a daily intraperitoneal $0.2 \mathrm{ml}$ normal saline for fifteen respective days. The animal were fasted for 12 hours after last does administration. Blood samples were collected, and the sera obtained. Analysis showed significant increase in the serum HDL level, and significant decrease in LDL concentration. A $P<0.05$ was considered significant.
\end{abstract}

Key words: Adiponectin ; HDL : LDL.

Abbreviations:

HDL : High-Density Lipoprotein.

LDL: Low-Density Lipoprotein.

SEM: Standard Error of the Mean.

\section{Introduction}

Adiponectin hormone is synthesized
and released by the adipocytes [1].Adiponectin is related to the complement factor $\mathrm{Clq}$ family in its structure, and also known as AdipoQ, apM1, ACRP30 and GBP28 [2, 3].Adiponectin is also synthesized by liver and skeletal muscle [4, 5].Adiponectin is encoded as a protein has 244 amino acid, and its gene found on chromosome 3q27 [6].Adiponectin is involved in the regulation of energy balance. It enhance insulin sensitivity then it regulates lipid and glucose metabolism, so the result it regulates energy homeostasis [7, 8].Adiponectin has anti-atherogenic and anti- inflammatory effects [9].Its antiinflammatory property is due to its ability to inhibit proliferation of smooth muscle,

\section{Materials and Methods}

The animals

Thirteen female Wistar albino rats weighing $230-310 \mathrm{~g}$ ( $6-7 \mathrm{WK}$ old ), were used and divided randomly into two equal adhesion of monocyte and foam cell formation [1].Insulin resistance and type 2 diabetes have been noticed to accompany low plasma adiponectin [10, 11].Adiponectin has influence on the metabolism of bone cells, this means that adiponectin has a role in bone homeostasis [12].There are two distinct receptors for adiponectin found in several tissues and cell lines thereby the hormone exerts its functional activities, they are AdipoR1 and AdipoR2 [13, 14]. These two receptors enable adiponectin fulfil different performances. Through the AdipoR1 the adiponectin regulates energy metabolism, while with AdipoR2 it is implicated in energy dissipation, oxidative stress and inflammation [15].

groups, treated and control groups.The animals were housed in appropriate cages with 12 hours light/dark cycle (Light time starts at $6 \mathrm{am}$ through $6 \mathrm{pm}$, and dark period 


$\begin{array}{llll}\text { AL-Qadisiya Journal of Vet.Med.Sci. } & \text { Vol./12 } & \text { No./2 } & 2013\end{array}$

from $6 \mathrm{pm}$ up to 6am ). Pellet food and municipal tap water were freely available.The animals were left for week in the animal house before the start of experiment to adapt to experimental environment.Each animal in the experimental group received a daily intraperitoneal injection of 25 microgram adiponectin hormone dissolved in $0.2 \mathrm{ml}$ physiological saline (0.9) for fifteen respective days. In the same time each animal in the control group received a daily intraperitoneal dose $0.2 \mathrm{ml}$ of physiological saline - for fifteen respective days.

\section{The Hormone and Preparation of Does}

Six vial of adiponectin hormone produced by Pepro Tech EC ( UC ) were used, each vial contains $1 \mathrm{mg}$ of adiponectin. The adiponectin does (25microgram dissolved in $0.2 \mathrm{ml}$ physiological saline) prepared by dissolving one vial of adiponectin in $8 \mathrm{ml}$ of sterile 0.9 normal saline immediately before use.The next vial was only used after the depletion of the preceding one.

\section{Collection of blood}

The animal were fasted for 12 hours after last does administration. The blood was drawn in separated tubes by cardiac puncture under chloroform anaesthesia, and left to coagulate, then centrifuged at 3000 rpm for 10 minutes. The sera were kept in $20 \mathrm{C}^{\mathrm{o}}$ until analysis.

\section{HDL and LDL Measurement}

Serum HDL and LDL concentrations were measured by colorimetric enzymatic methods (Spectrophotometer: Shimadzu UV-Visible-1650 PC. Japan) and using commercial kit produced by Nanjing Jhancheng Bioengineering Institute (China). The protocol supplied by the manufacturer was followed. Measurements were taken in triplicate for the samples and the mean value for each sample was determined.

\section{Statistical Analysis}

All values were expressed as mean \pm SEM. The level of statistical significance was set at $p<0.05$. Differences between the treated and control groups were assessed using Student $\square \mathrm{s} t$-test. Statistical analysis were achieved by using version 16.0 of the Statistical Package for the Social Sciences (SPSS) programme .

\section{Results}

Results showed significant increases in the serum levels of HDL, and significant decrease in LDL concentration in the treated group when compared with control group.Figure -1- presents the significant difference in serum HDL concentration between the treated and control groups. The concentration in control group was 0.90 $\mathrm{mmo} / \mathrm{l} \pm 0.06$. While it was $0.99 \mathrm{mmo} / / \mathrm{l} \pm$ 0.8 in treated one.Figure -2- shows the significant difference in serum LDL concentration between the control and treated groups. The concentration in control group was $1.24 \mathrm{mmol} / \mathrm{l} \pm 0.12$. While it was $1.13 \mathrm{mmo} / \mathrm{l} \pm 0.18$ in the treated group. 

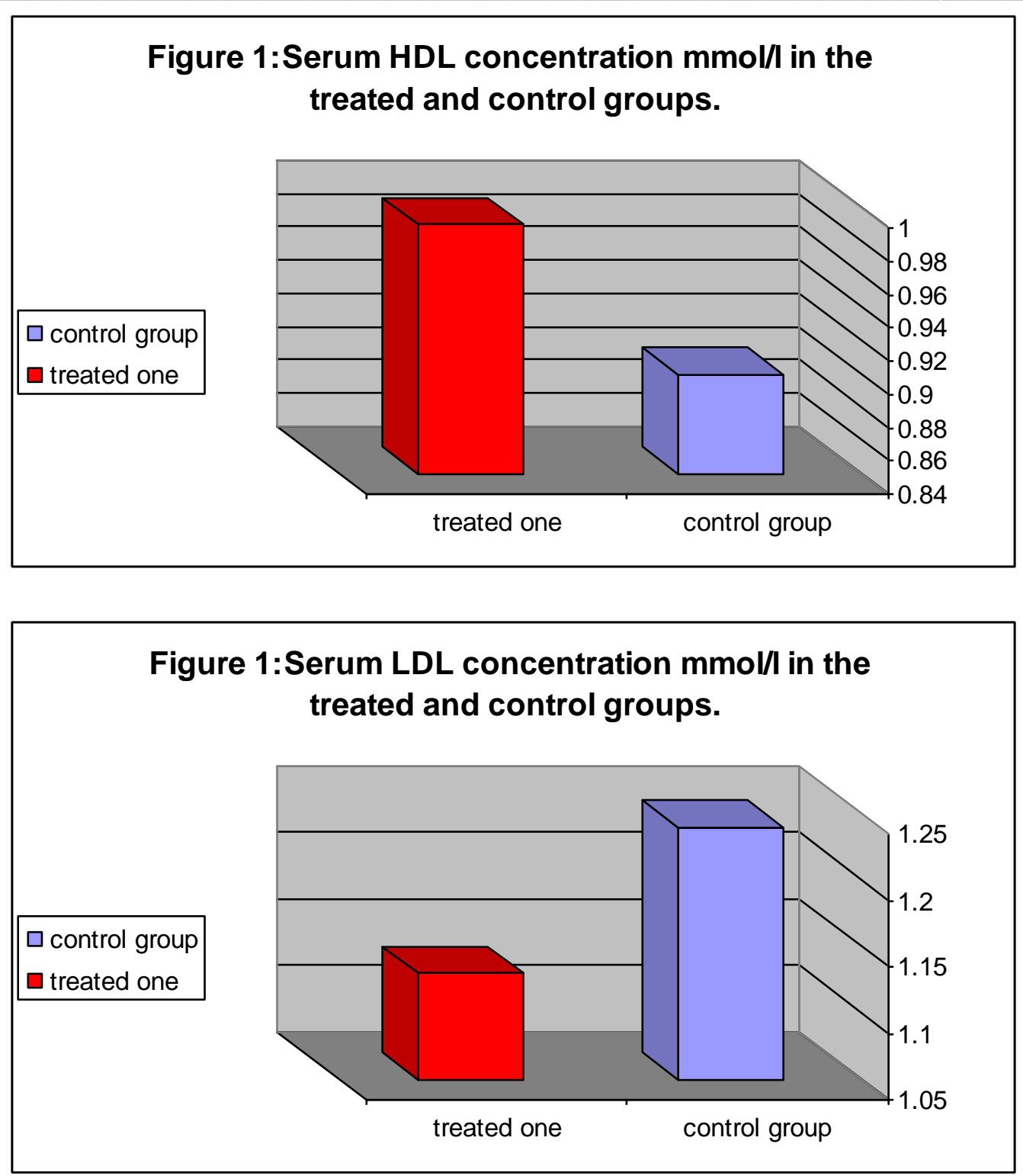

\section{Discussion}

LDL is the main cholesterol carrier, and it delivers cholesterol to cells throughout the body. LDL cholesterol is designated "bad" cholesterol because it associated with increased deposition of cholesterol in arterial wall. However, the LDL cholesterol is essential for supplying cells with cholesterol they require to synthesize cell membranes and steroid hormones.HDL removes excess cholesterol from tissue and blood, then delivers the cholesterol to the liver to be secreted into the bile or converted to bile salts [16].Almost all the lipoproteins are formed in the liver. Small quantities of highdensity lipoproteins are synthesized in the intestinal epithelium during the absorption of fatty acids from the intestines [17].Adiponectin might inhibit hydroxymethylgutaryl- coenzyme A (HMG-CoA) reductase. This inhibition decreases cholesterol synthesis and increases LDL receptors which causes high reduction in plasma level of LDL [18]. 
Adiponectin might stimulate the liver to increase secretion of cholesterol with bile or as bile salts, activity ends up in decrease of LDL level.The important factor in the development of atherosclerosis is not necessarily total plasma cholesterol concentration but the ratio of LDL to HDL in plasma, the lower the ratio, the lower the risk [17].In this research the ratio in treated group got low due to reduction of LDL concentration and increasing HDL level.It has been established that there are receptors for adiponectin exist in the liver [19].With

\section{References}

1- Chen, M.P., Tsai, J.C., Chung, F.M., Yang, S.S., Hsing, L.L., Shin, S.J., Lee, Y.J. (2005). Hypoadiponectinemia is associated with ischemic cerebrovascular disease. Arterioscler. Thromb. Vasc. Biol. 25, 821-826.

2- Maeda, K., Okubo, K., Shimomura, I., Funahashi, T., Matsuzawa, Y. and Matsubara, K. (1996) CDNA cloning and expression of a novel adipose specific collagen-like factor, apM1 (AdiPose Most abundant Gene transcript 1). Biochem. Biophys. Res. Commun. 221, 286-289.

3- Scherer, P.E., Williams, S., Fogliano, M., Baldini, G. and Lodish, H.F. (1995). A novel serum protein similar to $\mathrm{C} 1 \mathrm{q}$, produced exclusively in adipocytes. J. Biol. Chem. 270, 26746-26749.

4- Nakayama H, Otabe S, Yuan X, Ueno T, Hirota N, Fukutani T. (2009). Effects of adiponectin transgenic expression in liver of nonalcoholic steatohepatitis model mice. Metabolism;58:901-8.

5- Liu BH, Wang PH, Wang YC, Cheng WM, Mersmann HJ, Ding ST. (2008). Fasting regulates the expression of adiponectin receptors in young growing pigs. $\mathrm{J}$ Anim Sci;86:3377-84. this fact it become possible to say that the adiponectin has stimulated the liver to produce more HDL.In conclusion, this research puts adiponectin hormone a strong candidate to be used in treatment of some types of metabolic disorders, particularly those problems relate to insulin deficiency and blood cholesterol level.This investigation have found that adiponectin increases HDL and reduces LDL levels in the blood. These findings are crucial factors for maintaining good health.
6- Maeda K, Okubo K, Shimomura I, Funahashi T, Matsuzawa Y, Matsubara K. cDNA. (1996). Cloning and expression of a novel adipose specific collagen-like factor: apM1 (AdiPose most abundant gene transcript 1). Biochem Biophys Res Commun; 221(2):286-9.

7- Rasouli, N. and Kern, P.A. (2008) Adipocytokines and the metabolic complications of obesity. J. Clin. Endocrinol. Metab. 93, S64-73.

8- Hug, C. and Lodish, H.F. (2005). The role of the adipocyte hormone adiponectin in cardiovascular disease. Curr. Opin. Pharmacol. 5, 129-134.

9- Hu, E., Liang, P., Spiegelman, B.M. (1996). AdipoQ is a novel adiposespecific gene dysregulated in obesity. J. Biol. Chem. 271, 10697-10703.

10- Spranger J, Kroke A, Möhlig M, Bergmann MM, Ristow M, Boeing H.(2003). Adiponectin and protection against type 2 diabetes mellitus. Lancet;361:226-8.

11- Yamauchi T, Kamon J, Waki H, Terauchi Y, Kubota N, Hara K. (2001). The fatderived hormone adiponectin reverses insulin resistance associated with both 
lipoatrophy and obesity. Nat Med 7:941-6.

12- Berner HS, Lyngstadaas SP, Spahr A, Monjo M, Thommesen L, Drevon CA, Syversen U, Reseland JE. (2004). Adiponectin and its receptors are expressed in boneforming cells. Bone 35:842-849.

13- Wang Y, Lam KS, Yau MH, Xu A. (2008).

Post-translational modifications of adiponectin: mechanisms and functional implications. Biochem J;409 (3): 623-33.

14- Lang K, Ratke J. (2009). Leptin and Adiponectin: new players in the field of tumor cell and leukocyte migration. Cell Commun Signal ;7:27.

15- Yamauchi T, Nio $Y$, Maki T, Kobayashi M, Takazawa T, Iwabu M.(2007). Targeted disruption of
AdipoR1 and AdipoR2 causes abrogation of adiponectin binding and metabolic actions. Nat Med; 13(3):332-9.

16- Widmair Eric P. Raff Hershel. Strang Kevin T. (2011). Vander's Human Physiology. Twlfth Edition. McGraw-Hill of the McGraw-Hill Companies. New York.

17- Fielding BA, Frayn KN. (2003). Lipid metabolism. Curr Opin Lipidol 14:389.

18- Hilgemann DW. (2003). Getting ready for the decade of the lipids. Annu Rev Phsiol 65:697.

19- Shetty S, Kusminski CM, Scherer PE. (2009). Adiponectin in health and disease: evaluation of adiponectintargeted drug development strategies. Trends Pharmacol Sci; 30(5):234-9.

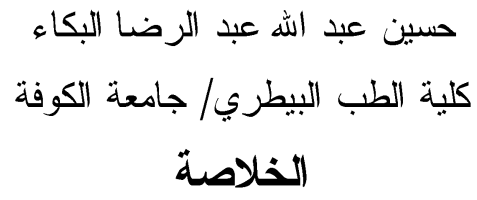

اجريت هذه التجربة لمعرفة تأثير هرمون الاديبونكتين Adiponectin Hormone على مستوى البروتينات الدهنية العالية الكثافة (HDL) و البروتينات الدهنية واطئة الكثافة (LDL) في أناث الجرذان، استخدم لهذا الغرض ثلاثون انثا من الجرذان قسمت عشوائيا إلى مجموعتين.اعطت كل انثا من مجموعة المعاملة جرعة يومية مقدارها 25 مايكرو غرام من الاديبونكتين مذابا في 0.2 مل من الملح الفيسولوجي في الغشاء المساريقي ولمدة 15 يوما متتاليا في حين اعطت كل واحدة من مجموعة السيطرة جرعة يومية مقدارها 0.2 مل من الملح الفيسولوجي في الغشاء المساريقي ولمدة 15 يوما متتاليا .بعد اثني عشر ساعة صيام من اخر جرعة تم جمع عينات الدم ثم استحصل السيروم Serum واجري تحديد مستوى كل من HDL و

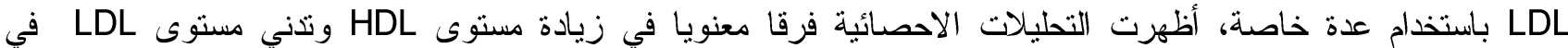
مجموعة المعاملة عند مقارنتها مع مجموعة السيطرة. 